\title{
A Geographic information system based soil loss and sediment estimation in Zingin watershed for conservation planning, highlands of Ethiopia
}

\author{
Gizachew Ayalew \\ Amhara Design and Supervision Works Enterprise (ADSWE), Bahir Dar, Ethiopia
}

Email address:

gizachewayalew75@yahoo.com

\section{To cite this article:}

Gizachew Ayalew. A Geographic Information System Based Soil Loss and Sediment Estimation in Zingin Watershed for Conservation Planning, Highlands of Ethiopia. International Journal of Science, Technology and Society. Vol. 3, No. 1, 2015, pp. 28-35. doi: $10.11648 / j$.ijsts.20150301.14

\begin{abstract}
Zingin watershed is one of the most erosion-prone watersheds in the highlands of Ethiopia which received little attention. This study was, therefore, carried out to spatially predict the soil loss rate of the watershed with a Geographic Information System (GIS) and Remote Sensing (RS). Revised Universal Soil Loss Equation (RUSLE) adapted to Ethiopian conditions was used to estimate potential soil losses by utilizing information on rainfall erosivity (R) using interpolation of rainfall data, soil erodibility (K) using soil map, vegetation cover $(\mathrm{C})$ using satellite images, topography (LS) using Digital Elevation Model (DEM) and conservation practices (P) using satellite images. Based on the analysis, the total annual soil loss potential of the study watershed Based on the analysis, the mean and total annual soil loss potential of the study watershed was 9.10 ton tons $/ \mathrm{yr}$ and $57750.15 \mathrm{t} / \mathrm{yr}$, respectively. About $78.31 \%$ (4969.63 ha) of the watershed was categorized none to slight class which under SLT values ranging from 5 to 11 tons $\mathrm{ha}^{-1} \mathrm{yr}^{-1}$. The remaining $21.69 \%$ (1376.48 ha) of land was classified under moderate to high class about several times the maximum tolerable soil loss (11 tons ha $\left.{ }^{-1} \mathrm{y}^{-1}\right)$. The study demonstrates that the RUSLE together with GIS provide a good estimate soil loss rate over areas.
\end{abstract}

Keywords: Soil Erosion, RUSLE, GIS, Zingin Watershed, Ethiopia

\section{Introduction}

Agriculture is the mainstay of the Ethiopia's economy where its production is highly dependent on natural resources (Akililu and Graaff, 2007). It accounts for the employment of $90 \%$ of its population, over $50 \%$ of the country's gross domestic product (GDP) and over $90 \%$ of foreign exchange earnings (ECACC, 2002). However, low productivity characterizes the country's agriculture.

Land degradation is a major cause of poverty in Ethiopia (Mitiku et al, 2002). The degradation mainly manifests itself in terms of lands where the soil has either been eroded away and/or whose nutrients have been taken out to exhaustion without any replenishment. Soil erosion by water and its associated effects are recognized to be severe threats to the national economy of the country and mainly occur in the highlands of the country (Hurni, 1993; Sutcliffe, 1993; Tamene, 2005). In the Ethiopian highlands only, an annual soil loss reaches 200-300 tons $\mathrm{ha}^{-1} \mathrm{yr}^{-1}$ (FAO, 1984; Hurni,
1993). The average crop yield from a piece of land in Ethiopia is very low mainly due to soil fertility decline associated with removal of topsoil by erosion (Sertu, 2000).

Despite the severity of soil erosion and its consequences in the study watershed, there have been few studies at regional level to quantify erosion rates at watershed scale. In addition, the soil loss estimated by different researchers could vary for the same environment. This implies that there is a need to have site specific at watershed level information on soil erosion in order to support timely information for decision makers. It was, therefore, essential to assess rates of soil loss and develop a soil loss intensity map of the study watershed using RUSLE within a GIS environment and identify severity areas for specific soil conservation plans.

\section{Materials and Methods}

\subsection{Description of the Study Watershed}

Zingin watershed is located in Awi Zone at about $450 \mathrm{~km}$ 
northwestern of Addis Ababa. The watershed lies within 1198643 to $1216898 \mathrm{~m}$ North and 270383 to $278457 \mathrm{~m}$ East in UTM coordinates with an altitude ranges of 2315 up to 2874 m.a.s.1. (Figure 1) with the total area of 6346.17 ha.

\subsection{Methods}

The input thematic data included rainfall, soil units, slopes and land use/cover and determined as follow.

\subsubsection{Determination of Soil Loss Factors}

\subsubsection{Rainfall Erosivity Factor}

The monthly amounts of precipitation for the watershed were collected over 15 years by the Amhara Regional
Meteorological Agency. Monthly rainfall records from these meteorological stations covering the period 1998-2012 were used to calculate the rainfall erosivity Factor (R-value). The mean annual rainfall was first interpolated to generate continuous rainfall data for each grid cell by "3D Analyst Tools Raster Kriging Interpolation" in ArcGIS environment (Figure 3). Then, the R-value corresponds to the mean annual rainfall of the watershed was found using the R-correlation established in Hurni (1985) to Ethiopia condition.

$$
\mathrm{R}=-8.12+0.562 \mathrm{P}
$$

Where $\mathrm{R}$ is the rainfall erosivity factor and $\mathrm{P}$ is the mean annual rainfall (mm).

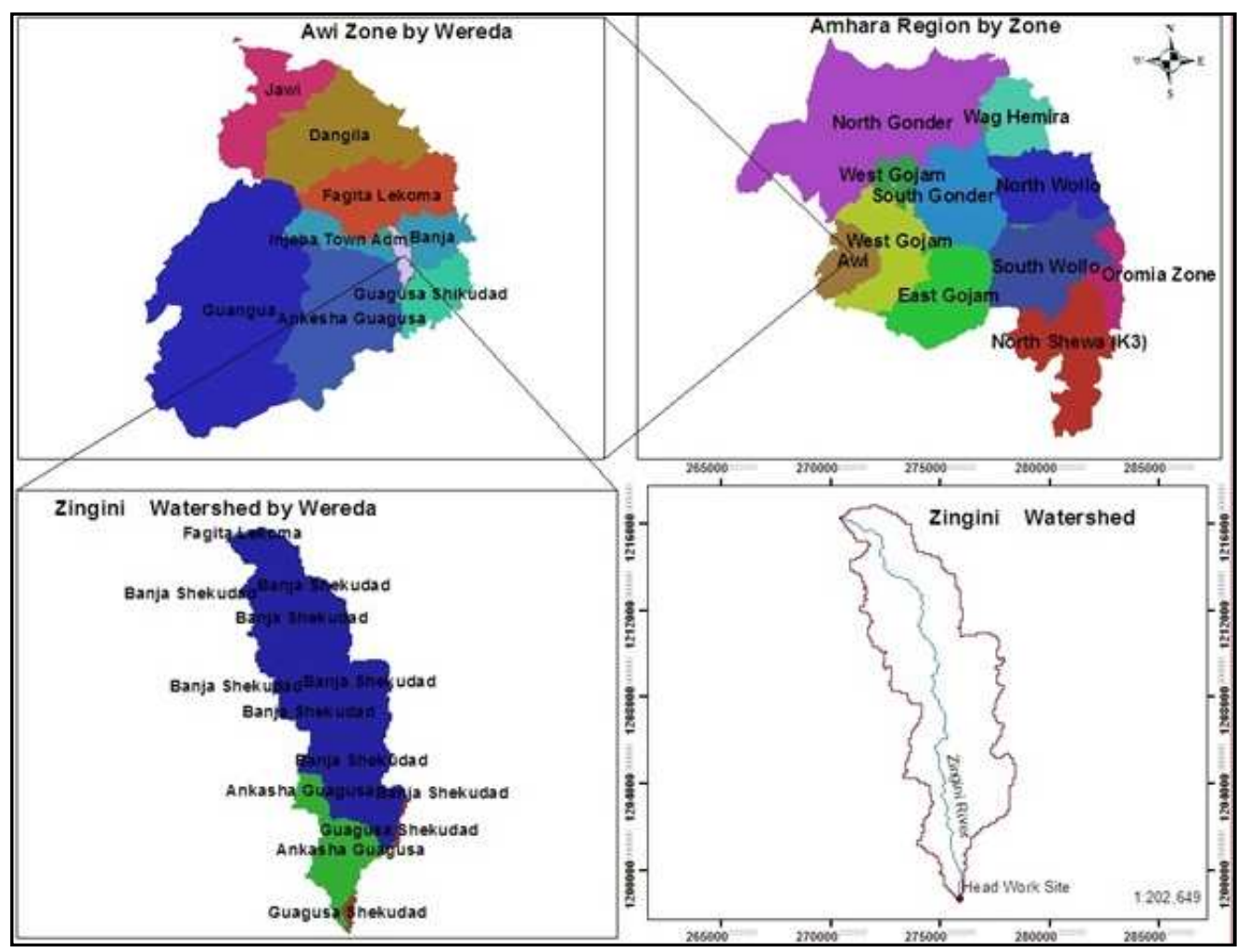

Figure 1. Location Map of Zingini Watershed

\subsubsection{Soil Erodibility Factor}

"Spatial Analyst Tool Extract by Mask" in GIS environment was used to obtain soil units map of the study watershed from Amhara Regional digital soil map at 1:50,000 scale developed by DSA and SCI (2006). The soil erodibility $(\mathrm{K})$ factor for the watershed was estimated based on soil unit types referred from FAO (1989) soil database adapted to Ethiopia by Hurni (1985) and Hellden (1987). Finally, the resulting shape file was changed to raster with a cell size of 30x30 m. The raster map was then reclassified based on their erodibility value as shown in table 1 .

Table 1. Soil Types and their Areas

\begin{tabular}{lllll}
\hline \multirow{2}{*}{ No } & \multirow{2}{*}{ Soil Type } & \multirow{2}{*}{ Erodibility (K Factor) } & Area Coverage & Percent (\%) \\
\cline { 4 - 5 } & & & Hectare (ha) & 3.91 \\
2 & Chromic Vertisols & 0.2 & 248.17 & 94.40 \\
2 & Dystric Nitosols & 0.15 & 5990.63 & 1.69 \\
3 & Pellic Vertisols & 0.2 & 107.37 & 100 \\
Total & & & 6346.17 & \\
\hline
\end{tabular}

\subsubsection{Slope Length and Slope Steepness}

The $30 \mathrm{~m}$ spatial resolution DEM (digital elevation model) was used to generate slope as shown figure 6 by using "Spatial Analyst Tool Surface Slope" in ArcGIS 10.1 environment. The flow accumulation and slope steepness 
were computed from the DEM using ArcGIS. Flow accumulation and slope maps were multiplied by using "Spatial Analyst Tool Map Algebra Raster Calculator" in Arc GIS 10.1 environment to calculate and map the slope length (LS factor) as shown in equation (2) and figure 4 and defined by (Wischmeier and Smith 1978).

$$
\begin{array}{rr}
\mathrm{LS}=(\text { Flow Accumulation*Cell size } / 22.13)^{0.4} *(\mathrm{Sin} \\
\text { slope } / 0.896)^{1.3} & \text { Equation }(2)
\end{array}
$$

Where: Cell size- represents the field slope length -22.13 is the length of the research field plot

\subsubsection{Land Use/Cover Data and Crop Management Factor}

A land-use and land-cover map of the study area was prepared from LANDSAT satellite image acquired on 2013 and supervised digital image classification technique was employed using ENVI 5.0 software. A field checking effort also was made in order to collect ground truth information. The LAND SAT satellite image acquired on 2013 was used to classify the current land use and land cover map of the watershed. Digital image processing operations were carried out using ENVI 5.0 software. In addition, ground truth data were used as a vital reference for supervised classification, accuracy assessment and validation of the result. In supervised image classifications technique, land use and land cover types were classified so as to use the classified images as inputs for generating crop management (C) factor and support practice (P) factor. Based on the land cover classification map, a corresponding $\mathrm{C}$ value obtained from Hurni (1985) was assigned in a GIS environment (Table 3).

\subsubsection{Erosion Management Practice Factor (P-value)}

The P-factor was assessed using major land cover and slope interaction adopted by Wischmeier and Smith (1978) for Ethiopia condition. The data related to management or support practices of the watershed were collected during the field work. Therefore, values for this factor were assigned considering local management practices and it was taken the weighed value for similar land use types. The corresponding $P$ values were assigned to each land use/land cover classes and slope classes and the P factor map was produced.

\subsubsection{Soil Loss Analysis}

The overall methodology involved the use of the RUSLE in a GIS environment with factors obtained from meteorological stations, soil map, topographic map, Satellite Images and DEM as shown in equation 4, figure 5 and 6 . Annual soil loss rate was determined by a cell-by-cell analysis of the soil loss surface by superimposing and multiplying the respective RUSLE factor values (R, K, LS, C and P) interactively by using "Spatial Analyst Tool Map Algebra Raster Calculator" in ArcGIS 10.1 environment as shown equation (3) adopted from the recommendations of Hurni (1985) and Gebreselassie (1996). For the purpose of identifying priority areas for conservation planning, soil loss potential of the watershed was then categorized into different severity classes following FAO \& UEP (1984) guide line.

$$
\mathrm{A}=\mathrm{LS}^{*} \mathrm{R}^{*} \mathrm{~K}^{*} \mathrm{C} * \mathrm{P}
$$

Where $\mathrm{A}$ is the annual soil loss (metric tons $\mathrm{ha}^{-1} \mathrm{yr}^{-1}$ ); $\mathrm{R}$ is the rainfall erosivity factor [MJ $\left.\mathrm{mm} \mathrm{h}^{-1} \mathrm{ha}^{-1} \mathrm{yr}^{-1}\right] ; \mathrm{K}$ is soil erodibility factor [metric tons $\mathrm{ha}^{-1} \mathrm{MJ}^{-1} \mathrm{~mm}^{-1}$ ]; LS = slope length factor (dimensionless); $\mathrm{C}$ is land cover and management factor (dimensionless); and $\mathrm{P}$ is conservation practice factor (dimensionless). Ground truth data collected by GPS were used for checking and validation of results.

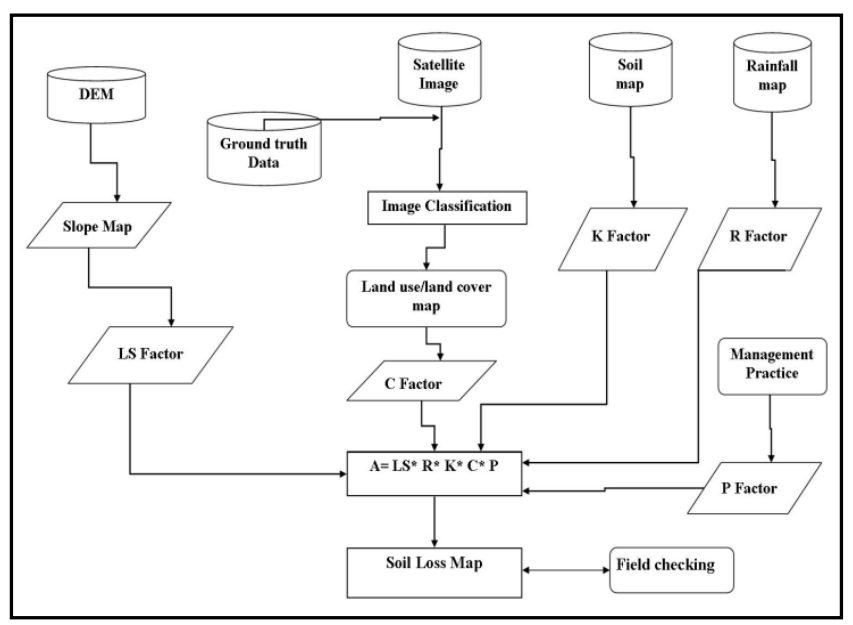

Figure 2. Flow Chart showing the GIS based Soil Loss Estimation

\subsubsection{Sediment Yield}

The sediment delivery ratio (SDR) denotes the ratio of the sediment yield at a given stream cross section to the gross erosion from the watershed upstream from the measuring point (Julien, 1998). To generate the sediment yield at the outlet, empirical equations were carried out.

$$
\mathrm{SDR}=\mathrm{A}^{-0.2}
$$

equation (3)

Where, SDR denotes the sediment delivery ratio and area of the watershed. The SDR physically means the ratio of the sediment routed to the outlet over the watershed, both overland and channel.

Sediment yield is commonly estimated by the following empirical formula:

$$
\mathrm{Sy}=\mathrm{E}^{*}\left(1 / \mathrm{A}^{0.2}\right)
$$

equation (4)

Where, $\mathrm{S}_{\mathrm{y}}=$ Sediment yield (ton) at the watershed out let; $\mathrm{E}=$ total erosion (ton); $\mathrm{A}=$ watershed area (ha)

\section{Results and Discussion}

\subsection{Rainfall Erosivity Factor (R)}

Soil loss is closely related to rainfall partly through the detaching power of raindrops striking the soil surface and partly through the contribution of rain to runoff (Morgan, 1994). The soil loss is closely related to rainfall partly through the detaching power of raindrop striking the soil surface and partly through the contribution of rain to runoff. The annual rainfall of the watershed is ranging 1500-2000 $\mathrm{mm}$. The result showed that $\mathrm{R}$-factor value in the watershed ranged between 
915.88 to $1055.88 \mathrm{MJmmha}^{-1} \mathrm{yr}^{-1}$ with higher values occurring

in the watershed (Table 2 and Figure 3).

Table 2. Rainfall Erosivity

\begin{tabular}{lllll}
\hline No & Rainfall class $\mathbf{m m}$ & Rainfall erosivity factor $\left(\mathbf{M J} \cdot \mathbf{m m} \cdot \mathbf{h a}^{\mathbf{- 1}} \cdot \mathbf{y r}^{\mathbf{- 1}}\right.$ ) & Area (ha) & Area $(\%)$ \\
\hline 1 & $1500-1800$ & 915.88 & 897.95 & 14.15 \\
2 & $1800-2000$ & 1055.88 & 5448.23 & 85.85 \\
Total & & 6346.17 & 100 \\
\hline
\end{tabular}

\subsection{Soil Erodibility Factor (K)}

The erodibility of a soil is an expression of its inherent resistance to particle detachment and transport by rainfall. It is determined by the cohesive force between the soil particles, and may vary depending on the presence or absence of plant cover, the soil's water content and the development of its structure (Wischmeier and Smith, 1978). The soil erodibility factor $(\mathrm{K})$ represents the effect of soil properties and soil profile characteristics on soil loss (Renard et al., 1997). Erodibility depends essentially on the amount of organic matter in the soil, the texture of the soil, the structure of the surface horizon and permeability (Robert \& Hilborn, 2000). The results indicated that soil erodibility value in the study

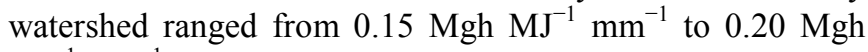
$\mathrm{MJ}^{-1} \mathrm{~mm}^{-1}$ (table 3 and figure 4).

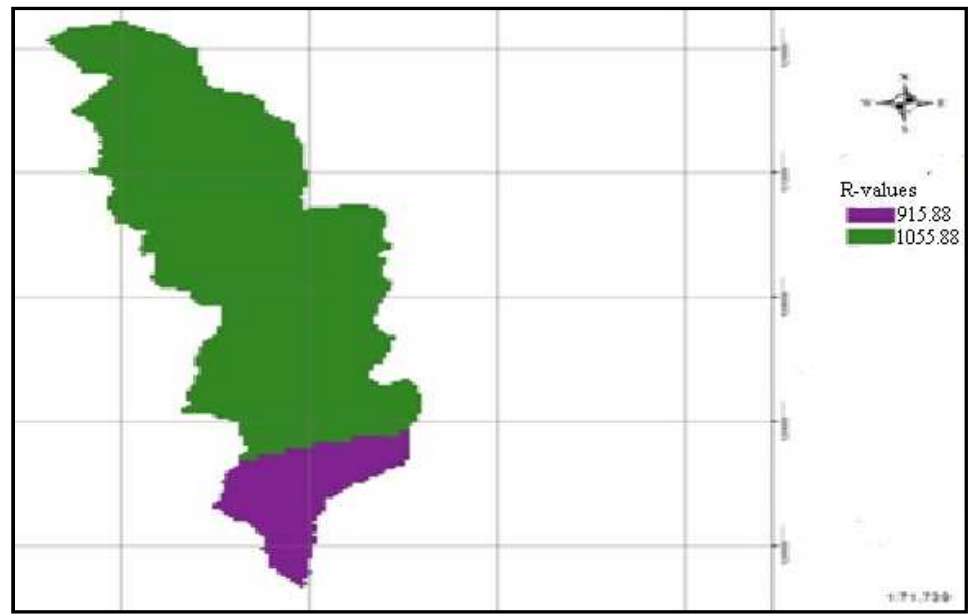

Figure 3. Erosivity Factor Map

Table 3. Soil Type and Erodibility Coverage

\begin{tabular}{lllll}
\hline \multirow{2}{*}{ No } & \multirow{2}{*}{ Soil Type } & \multirow{2}{*}{ Erodibility (K Factor) } & Area Coverage & Percent (\%) \\
\cline { 4 - 5 } & & & Hectare (ha) & 3.91 \\
2 & Chromic Vertisols & 0.2 & 248.17 & 94.40 \\
3 & Dystric Nitosols & 0.15 & 5990.63 & 1.69 \\
Total & Pellic Vertisols & 0.2 & 107.37 & 100 \\
\hline
\end{tabular}

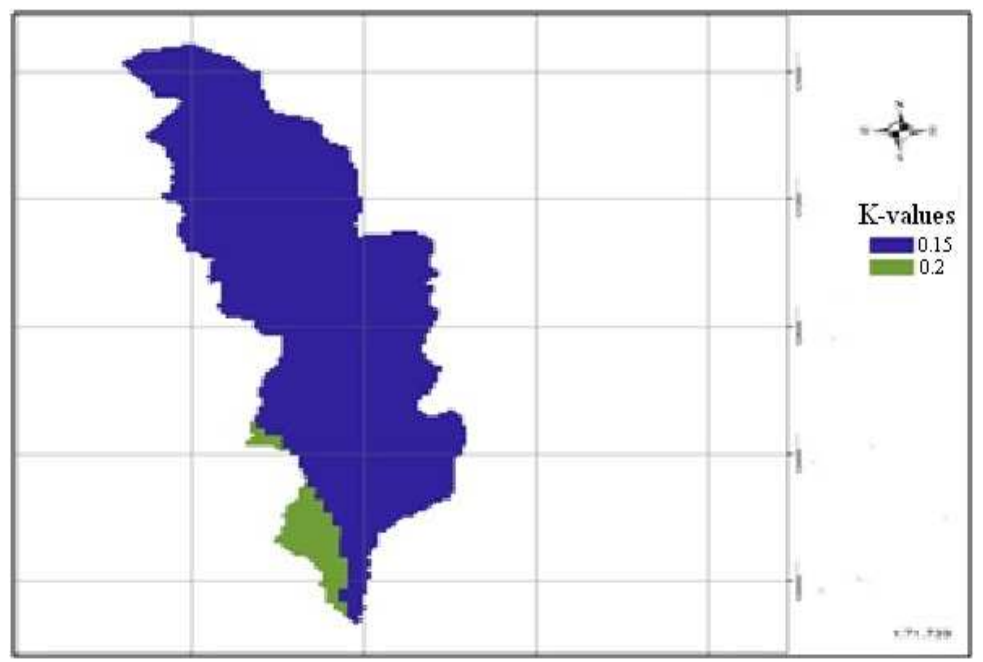

Figure 4. Soil Erodibility Factor Map 


\subsection{Slope Length and Slope Steepness Factor}

The influence of topography on erosion is complex. The local slope gradient ( $\mathrm{S}$ sub-factor) influences flow velocity and thus the rate of erosion. Slope length (L sub-factor) describes the distance between the origin and termination of inter-rill processes. In RUSLE, the LS factor represents a ratio of soil loss under given conditions to that at a site with the "standard" slope steepness of $9 \%$ and slope length of 22 $\mathrm{m}$ plot (Robert \& Hilborn, 2000). The steeper and longer the slope, the higher is the erosion. Some researchers have argued that upslope drainage area is a better parameter when describing the influence of slope length on erosion, not slope length (Desmet \& Govers, 1996). The upslope drainage area for each cell in a DEM was calculated with multiple flow algorithms. As slope length increases, total soil erosion and soil erosion per unit area increase due to the progressive accumulation of runoff in the down slope direction. The slope length and slope steepness can be used in a single index, which expresses the ratio of soil loss as defined by (Wischmeier and Smith 1978).

$$
\mathrm{LS}=(X / 22.13)^{\mathrm{m}}\left(0.065+0.045 S+0.0065 S^{2}\right)
$$

Where, Slope length $\mathrm{X}=$ over land flow length; Over land flow length $=\mathrm{Lo}=1 / 2 \mathrm{D} ; \mathrm{D}=$ Total Stream Length $/$ Watershed Area $=\mathrm{L} / \mathrm{A} ; \mathrm{D}=$ Drainage Density; $\mathrm{L}=59.38 \mathrm{~km} ; \mathrm{A}=63.46$ $\mathrm{km}^{2} ; \mathrm{D}=0.935708$ and $\mathrm{Lo}=534.355 \mathrm{~m}$

The attribute and spatial information on the present status of land use/land cover is a pre-requisite to identify and prioritize areas for soil conservation measures and minimizing further land degradation. The $\mathrm{C}$ - value is a ratio comparing the soil loss from land under a specific crop and management system to the corresponding loss from continuously fallow and tilled land. It represents the ratio of soil loss under a given crop to that of the base soil (Morgan, 1994). The cover management factor (C) measures the combined effect of cropping and management practices in agricultural system and the effect of ground cover, tree canopy and grass covers in reducing soil loss in nonagricultural condition (Wischmeier and Smith, 1978). It also reflects the effect of cropping and management practices on the soil erosion rate (Renard, Foster, Weesies, McCool, and Yoder, 1997). The results indicated that six land-use and land-cover classes were recognized in the watershed, dominantly by woodland (40\%) and crop cultivation $(26 \%)$ (Table 4 and Figure 6). These include built-up area, cultivated land, forest land, woodland, grass land and rockout crop. Crop management $\mathrm{C}$ factor values of the study watershed were ranging from 0.01 to 0.15 similar with the work of Morgan (2005).

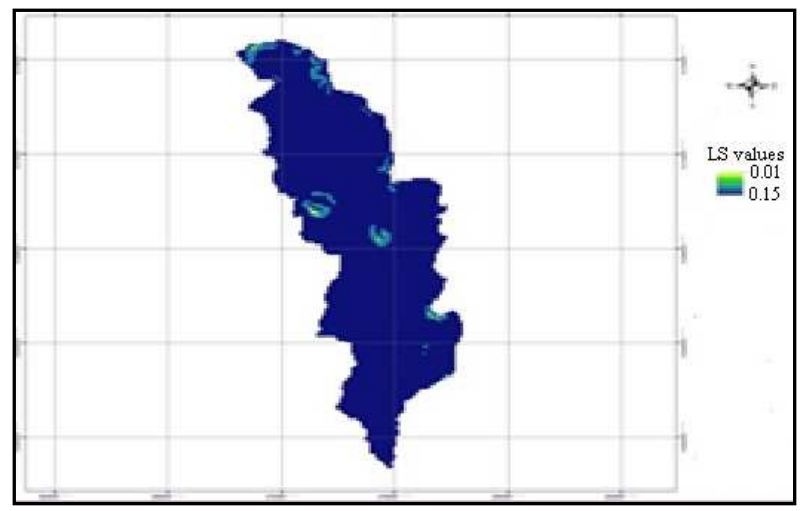

Figure 5. Steepness Factor Map

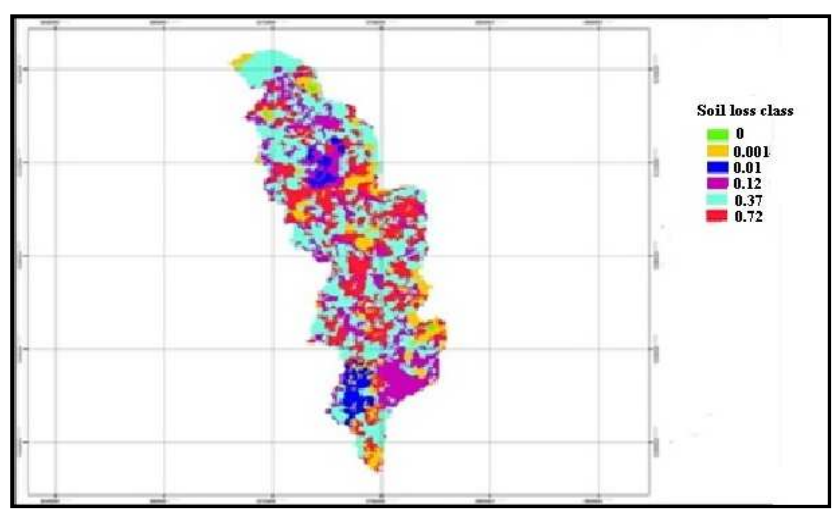

Figure 6. Derivation of Cover Factor from Cover Type

\subsection{Land Use and Land Cover and Crop Factor}

Table 4. Cover Management (C) Factor values of the study area

\begin{tabular}{lllll}
\hline \multirow{2}{*}{ No } & \multirow{2}{*}{ Land Cover Type } & \multirow{2}{*}{ Cover Factor (C Value) } & Area Coverage & Percent \\
\cline { 4 - 5 } & & & Hectare & 4.34 \\
& Built Up Area & 0.01 & 274.14 & 41.74 \\
2 & Cultivated Land & 0.37 & 2648.99 & 9.75 \\
3 & Forest Land & 0.001 & 618.56 & 19.15 \\
4 & Grass Land & 0.12 & 1215.05 & 24.78 \\
5 & Shrub and Bush Land & 0.72 & 1572.76 & 0.26 \\
6 & Water Body & 0 & 16.66 & 100 \\
\hline
\end{tabular}

\subsection{Management Practice Factor}

The conservation practices factor (p-values) reflects the effects of practices that will reduce the amount and rate of the water runoff and thus reduce the amount of erosion. It depends on the type of conservation measures implemented and requires mapping of conserved areas for it to be quantified. In the study area, there is only a small area that has been treated with terracing through the agricultural extension programme of the government, and these are poorly maintained as implementation was performed without participation of the local people. As data were lacking on 
permanent management factors and there were no management practices, I used the P-values suggested by Bewket and Teferi (2009), Wang and Sun (2002). Thus, the agricultural lands are classified into six slope categories and assigned P-values while all non-agricultural lands are assigned a P-value of 1.00 (Table 5 and Figure 7). Results indicated that most of the watershed is covered by wood land and crop cultivation.

Table 5. Land Management Factor $(P)$ values

\begin{tabular}{lll}
\hline Land Use Type & Slope (\%) & P-Factor \\
& $0-5$ & 0.1 \\
& $5-10$ & 0.12 \\
Cultivated Land & $10-20$ & 0.14 \\
& $20-30$ & 0.19 \\
& $30-50$ & 0.25 \\
Other land use & $50-100$ & 0.33 \\
Total & All & 1 \\
\hline
\end{tabular}

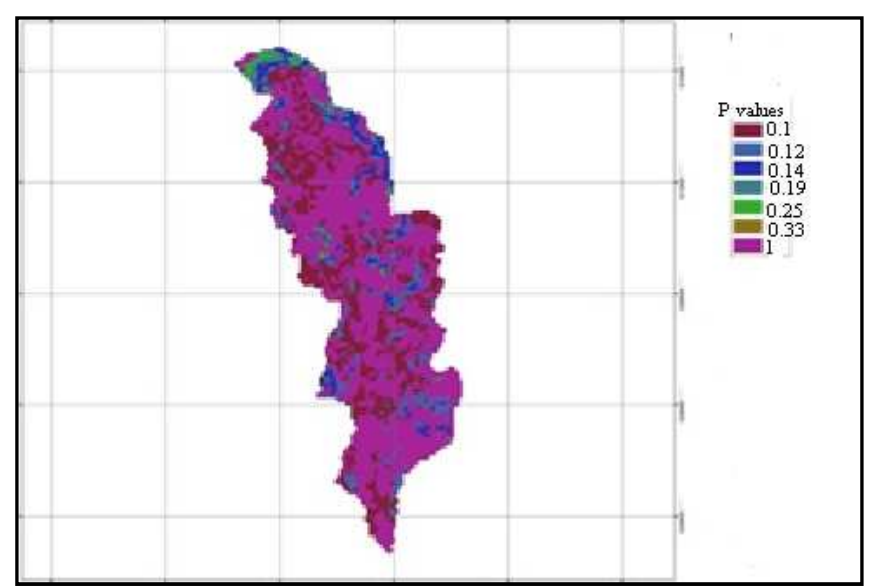

Figure 7. Derivative of Management Factor from Land Cover and Slope

\subsection{Soil Loss Estimation and Prioritization for Soil Conservation Planning}

The Revised Universal Soil Loss Equation (RUSLE) has been used widely all over the world (Mellerowicz, Ress, Chow and Ghanem, 1994) including Ethiopia (Kaltenrieder, 2007; Bewket and Teferi, 2009) because of its simplicity and limited data requirement. The advent of geographical information system (GIS) technology has allowed the equation to be used in a spatially distributed manner because each cell in a raster image comes to represent a field-level unit. Even though the equation was originally meant for predicting soil erosion at the field scale, its use for large areas in a GIS platform has produced satisfactory results (Mellerowicz, Ress, Chow and Ghanem, 1994; Renard, Foster,Wessies and Porter, 1994). By delineation of microwatersheds as erosion prone areas according to the severity level of soil loss, priority is given for a targeted and costeffective conservation planning (Kaltenrieder, 2007; Bewket \& Teferi, 2009).

As shown in Table 6 and Figure 8, Based on the analysis, the mean and total annual soil loss potential of the study watershed was 9.10 ton tons $/ \mathrm{yr}$ and $57750.15 \mathrm{t} / \mathrm{yr}$, respectively. About 78.31\% (4969.63 ha) of the watershed was categorized none to slight class which under SLT values ranging from 5 to 11 tons $\mathrm{ha}^{-1} \mathrm{yr}^{-1}$ (Renard, Foster, Weesies, McCool and Yoder, 1996). The remaining 21.69\% (1376.48 ha) of land was classified under moderate to high class about several times the maximum tolerable soil loss (11 tons ha ${ }^{-1} \mathrm{y}^{-}$ $\left.{ }^{1}\right)$ (Table 9 and Figure 12). Mati, Morgan, Gichuki, Quinton, Brewer and Liniger (2000) estimated average soil loss from croplands in the highlands of Ethiopia as a whole at 100 metric tons $\mathrm{ha}^{-1} \mathrm{yr}^{-1}$. In the highlands of Ethiopia and Eritrea soil losses are extremely high with an estimated average of 20 metric tons ha $^{-1} \mathrm{yr}^{-1}$ (Hurni, 1985) and measured amounts of more than 300 metric tons $\mathrm{ha}^{-1} \mathrm{yr}^{-1}$ on specific plots. Hurni (1993) estimated mean soil loss from cultivated fields as 42 metric tons $\mathrm{ha}^{-1} \mathrm{yr}^{-1}$. The average annual soil loss estimated by USLE from the entire Zingin watershed, northwestern Ethiopia was $24.95 \mathrm{t} / \mathrm{ha} / \mathrm{yr}$. Thus, the estimated soil loss rate was generally realistic, compared to results from previous studies.

Table 6. Soil Loss Summary of the Watershed

\begin{tabular}{llllll}
\hline \multicolumn{2}{l}{ Soil Loss Rating } & & \multicolumn{3}{c}{ Area Coverage } \\
\hline Class & Ton/ha/yr & $\mathbf{m m} / \mathbf{y r}$ & Descriptions & Hectare (ha) & Percent (\%) \\
\hline I & $0-5$ & $0-0.5$ & Non to slight & 3546.34 & 55.88 \\
II & $5-15$ & $0.5-1$ & Non to slight & 1423.29 & 22.43 \\
IV & $31-50$ & $2.5-4$ & Moderate & 1129.01 & 17.79 \\
V & $51-100$ & $4-6.5$ & High & 246.80 & 3.89 \\
VII & $>200$ & $>16.5$ & Very High & 0.67 & 0.01 \\
Total & & & & 6346.17 & 100 \\
\hline
\end{tabular}

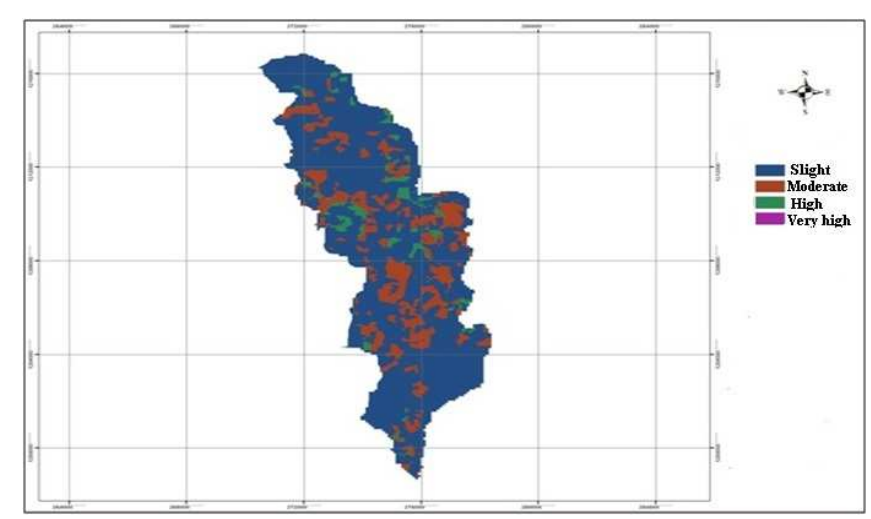

Figure 8. Soil Loss Map of the Watershed

\subsection{Sediment Yield}

Even though sediment yield is not as such important for diversion projects, it tells us how our top soils are being eroded by running water. Similar to the soil losses, sediment yields are also very high at the out let of the watershed. The transporting ability of the runoff to move all the eroded sediments is insufficient. As a result deposition occurs in reservoirs, depressions, at the toe of the hills where changes slope. Thus the amount of erosion in the watershed is generally more than the amount of sediment leaving the watershed at the outlet point. Hence, the sediment yield cannot be estimated from erosion estimates within the watershed unless additional data are available. Similar to that 
of erosion estimates, sediment yield is also calculated using empirical equation. The most common method for estimating sediment yield is sediment delivery ratio $\left(1 / \mathrm{A}^{0.2}\right)$, which is developed from reservoir survey, or measurement of suspended and bed loads at the gauging station and compared with that of erosion in the watershed.

$$
\mathrm{Sy}=\mathrm{E} *\left(1 / \mathrm{A}^{0.2}\right)
$$

Where, $\mathrm{S}_{\mathrm{y}}=$ Sediment yield (ton) at the watershed out let, $\mathrm{E}=$ total erosion (ton), $\mathrm{A}=$ Watershed area (ha), $\mathrm{S}_{\mathrm{y}}=$ $57750.15^{*}\left(1 / 6346.17^{0.2}\right)$ and

$$
\mathrm{Sy}=10024.22 \text { tons per year }
$$

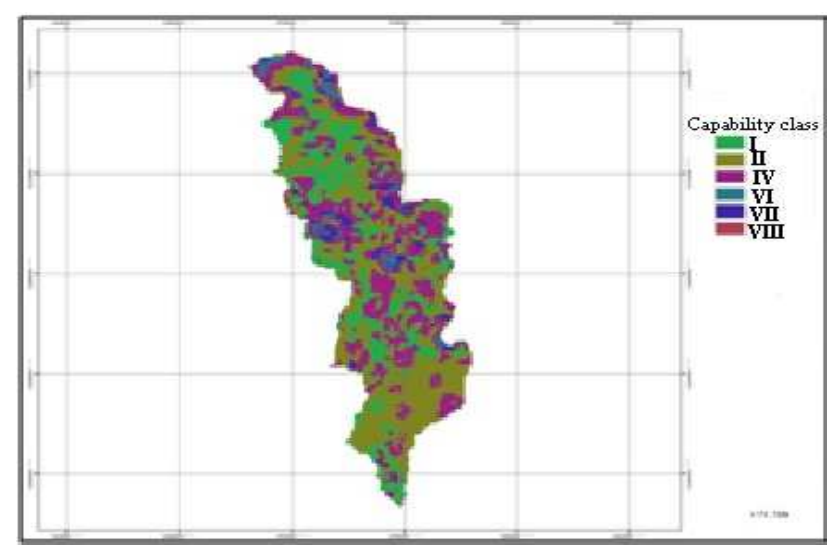

Figure 9. Land Capability Map of the Watershed

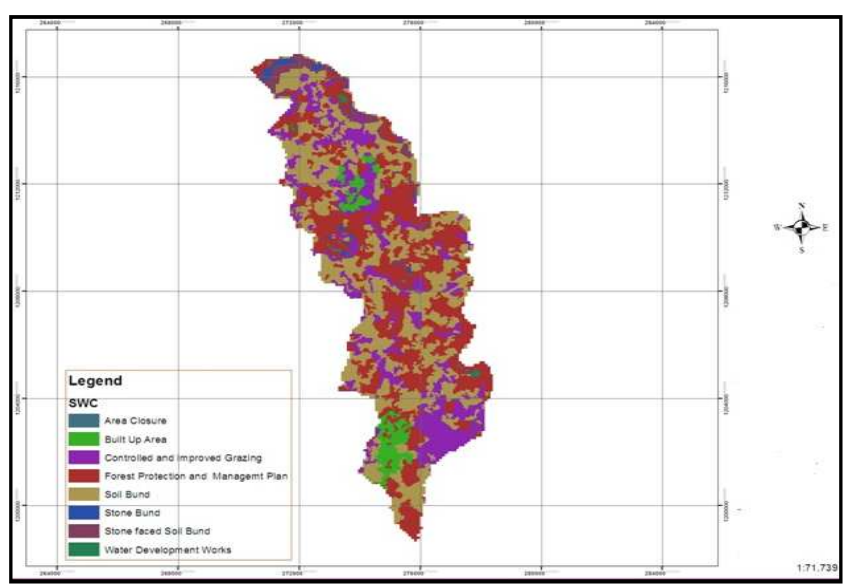

Figure 10. Soil water conservation development map of Zingini Watershed

\section{Conclusions and Recommendations}

The predicted amount of soil loss and its spatial distribution could facilitate comprehensive and sustainable land management through conservation planning for the watershed. Areas characterized by high to very high soil loss should be given special priority to reduce or control the rate of soil erosion by means of conservation planning. On the other hand, the management of moderate erosion hazard should be to protect them from further erosion, vegetation degradation and removal and stabilization through plantations. The study demonstrates that the RUSLE together with GIS and RS provides great advantage to estimate soil loss rate over areas. The parameter values of the factors are location specific and need to be calibrated to the specific area to enable reasonable prediction of the rate of soil loss.

\section{References}

[1] Akililu A. and Graaff De J.2007. Determinants of adoption and continued use of stone terraces for soil and water conservation in an Ethiopian highland watershed. Ecological Economics. 61:294-302.

[2] Bewket W. and Teferi E. 2009. Assessment of soil erosion hazard and prioritization for treat, ment at the watershed level: case study in the Chemoga watershed, Blue Nile basin, Ethiopia. Land degradation \& development. Published online in Wiley InterScience (www.interscience.wiley.com) DOI: 10.1002/ldr.944).

[3] Desmet P.J.J. and G. Govers.1996. A GIS procedure for automatically calculating the USLE LS factor on topographically complex landscape units. Journal of Soil and Water Conservation. 51.5:427-433.

[4] DSA (Development Studies Associates) and SCI (Shawel Consult International).2006. Potential Survey, Identification of Opportunities and Preparations of Projects Profiles and Feasibility Studies. Addis Ababa, Ethiopia.

[5] Ethiopian Central Agricultural Census Commission (ECACC).2002. Report on Preliminary Results of Area, Production and Yield of Temporary Crops (Meher Season Private Peasant Holding), Part II, on Ethiopian Agricultural Sample Enumeration, Addis Ababa, Ethiopia.

[6] FAO and UNEP.1984. Provisional Methodology for Assessment and Mapping of Desertification.

[7] FAO, Rome, Italy.

[8] FAO.1984. Ethiopian Highland reclamation Study (EHRS). Final Report, Vol. 1-2.Rome.

[9] FAO.1989. Reconnaissance Physical Land Evaluation in Ethiopia. Addis Ababa, Ethiopia.

[10] Gebreselasie, E.D., (1996). Soil erosion hazard assessment for land evaluation. Soil Conservation Research Program, University of Bern, Switzerland and the Ministry of Agriculture, Ethiopia. MSc Thesis, 1996:68-82.

[11] Hellden U.1987. An Assessment of Woody Biomass, Community Forests, Land Use and Soil Erosion in Ethiopia, Lund University Press, Lund.

[12] Hurni H.1985.Erosion-Productivity-Conservation Systems in Ethiopia. Proceedings 4th International Conference on Soil Conservation, Maracay, Venezuela, 654-674.

[13] Hurni H.1993. Land degradation, famine, and land resource scenarios in Ethiopia. In: Pimentel D. (Ed.) World soil erosion and conservation.Cambridge Univ. Press, 89-97.

[14] Julien PY, Frenette M (1998). Physical Processes Groverning Reservoir Sedimentation.

[15] Conference on Reservoir Sedimentation (pp. 121-142). Fort Collins, Colorado: Colorado State University. 
[16] Kaltenrieder J. 2007. Adaptation and Validation of the Universal Soil Loss Equation (USLE) for the EthiopianEritrean Highlands.MSc Thesis, University of Berne,Centre for Development and Environment Geographisches Institut.

[17] Mati BM, Morgan RPC, Gichuki FN, Quinton JN, Brewer TR, Liniger HP. 2000. Assessment of erosion hazard with the USLE and GIS: A case study of the Upper Ewaso $\mathrm{Ng}$ 'iro North basin of Kenya. International Journal of Applied Earth Observation and Geoinformation 2: 1-9.

[18] Mellerowicz KT, RessHW, Chow TL, Ghanem I. 1994. Soil conservation planning at the watershed level using the Universal Soil Loss Equation with GIS and microcomputer technologies: A case study. Journal of Soil and Water Conservation 49: 194-200.

[19] Mitiku H. Kjell E., Tor-Gunnar V. and Yibabe T.2002. Soil conservation in Tigray, Ethiopia, Noragric Report No. 5.

[20] Morgan, R.P.C.1994. Soil Erosion and Conservation. Silsoe College, Cranfield University.

[21] Morgan RPC.2005. Soil Erosion and Conservation ( $3^{\text {rd }}$ edn). Blackwell Science: Oxford.

[22] Renard, K.G., Foster, G.R., Weesies, G.A., McCool, D.K. and Yoder, D.C.1996. Predicting Soil Erosion by Water: A Guide to Conservation Planning with the Revised Universal Soil Loss Equation (RUSLE). USDA, Washington,DC.

[23] Renard K.G., Foster, G.R., Weesies G.A., McCool D.K., Yoder D.C.1997. Predicting soil erosion by water-a guide to conservation planning with the Revised Universal Soil Loss Equation (RUSLE).
[24] Renard K, Foster GR, Wessies GA, Porter JP.1994. Revised Universal Soil Loss Equation (RUSLE). Journal of Soil and Water Conservation 46:30-33.

[25] Robert P. S. and Hilborn D.2000. Factsheet: Universal Soil Loss Equation (USLE).Index No-572/751, Queen,s printer for Ontario.

[26] Sertu S.2000. Degraded Soil of Ethiopia and their management. Proceeding of FAO/ISCW expert consultation on management of degraded soils in Southern and East Africa. 2nd network meeting, 18-22 September 2000. Pretoria.

[27] Sutcliff JP (1993). Economic assessment of land degradation in the Ethiopian highlands: A case study. National conservation strategy secretariat, Ministry of planning and economic development, Addis Ababa, Ethiopia.

[28] Tamene L.2005.Reservoir siltation in the drylands of northern Ethiopia: causes, source areas and management options. PhD Thesis, Ecology and Development Series 30, Center for Development Research, University of Bonn. 84-138.

[29] Wang G, Hapuarachchi P, Ishidaira H, Kiem AS, Takeuchi K (2009) Estimation of soil erosion and sediment yield during individual rainstorms at catchment scale. Water Resource Manag. 23: 1447-1465.

[30] Wischmeier WH, Smith DD.1978. Predicting Rainfall Erosion Losses-A Guide to Conservation. Agricultural Handbook 537. US Department of Agriculture: Washington, DC. 